privilege and extending the prohibition of the Johnson Act to all state statutory questions would seem a more desirable method of change. Past congressional silence on this general subject makes any such drastic change seem unlikely; but, should the pressure of litigation in the rapidly expanding area covered by federal statutes become much greater, such a change might well become a practical necessity. ${ }^{70}$

\title{
REGULATION OF LABOR'S POLITICAL CONTRIBUTIONS AND EXPENDITURES: THE BRITISH AND AMERICAN EXPERIENCE
}

Section 304 of the Taft-Hartley Act, ${ }^{\mathbf{X}}$ which restricts labor's political contributions and expenditures, has not achieved the goals set for it by its original proponents. The legislation was designed primarily to protect members unwilling to finance the union's political activities and to reduce what was felt to be the undue influence of unions on elected officials and elections. ${ }^{2}$ But judicial construction has narrowed its coverage and left the law uncertain. If Section 304 is to be effective in terms of the policy considerations advanced in support of its passage, new legislative action is required. Some of the problems involved in regulation of labor's financial role in politics may be illuminated by comparing the American system with pertinent British law, which is more protective of individual freedom, less restrictive of political action by unions, and operates with greater clarity and certainty.

\section{THE UNITED STATES}

Before 1936 the political contributions and expenditures of American labor were small, sporadic and of little political importance. ${ }^{3}$ In the 1936 campaign labor spent $\$ 770,324.4$ Except for a negligible amount, 5 this money was contributed to the Democratic National Committee and other committees support-

${ }^{70}$ The Supreme Court has not, of course, actually stated the rules of federal jurisdiction in the sweeping language used in the analysis of Beiersdorf and Southern Railway in note $6_{5}$ supra; nor has the Court publicly announced its intention to curtail its appellate docket. Perfect conformance by the lower courts to these cases, however, would have the same effect as such an announcement. Developments to date indicate that the present trend will not be carried far enough to seriously alter the existing rights to federal jurisdiction. See notes $37,4 \mathrm{r}$, and 64 supra.

× 6 I Stat. 159 ( 1947 ), as amended, I8 U.S.C.A. \& 6 ro (r950).

2 See United States v. CIO, 335 U.S. I06, II 5 (1948). Concurring in the CIO case, Justice Rutledge stated that a third purpose was to preserve the purity of elections. Ibid., at I34. Not stressed in Senate debate on the Section (see text and notes at notes $33-36$ infra), this objective is too general to be of aid in defining the congressional intent underlying Section $30_{4}$ more exactly.

3 Overacker, Labor's Political Contributions, 54 Pol. Sci. Q. 56 (I939).

4 Special Committee to Investigate Campaign Expenditures in 1936, Sen. Rep. No. 151 , 75th Cong. rst Sess. 127-33 (1937) (hereafter cited as the Lonegran Report). See Overacker, op. cit. supra note 3 , for description and analysis of labor's role in the campaign.

$5 \$ 4,55^{\circ}$ to the Farmer-Labor Party. Lonegran Report, at $127-33$. 
ing the Democratic Party. ${ }^{6}$ Six hundred and nineteen thousand dollars came from unions affiliated with the newly formed CIO, and of this almost $\$ 500,000$ came from the United Mine Workers. ${ }^{7}$ Except for two Internationals and several locals, the AFL did not participate financially in the campaign. ${ }^{8}$ Largely due to the split between John L. Lewis and President Roosevelt, 9 labor's contributions to national political organizations in the I940 campaign totaled only a little over \$130,000. ${ }^{\text {xo }}$ As before, the bulk of labor's contributions came from the CIO and went to the Democratic Party. II

The emergence of labor as a political force in the r930's produced several legislative proposals aimed at regulating union political activity..$^{\mathbf{x}}$ Although none of these proposals resulted in federal legislation before r943, labor was, of course, subject to general election laws. The Corrupt Practices Act of I925 provides for publicity of the source and amount of campaign contributions and expenditures. ${ }^{13}$ Sections 13 and 20 of Hatch Act II set a limit of three million dollars on the amount which a political committee can spend in a calendar year, and limits the amount which a person or association can contribute to any one political committee during a calendar year to five thousand dollars. ${ }^{{ } 4}$ But the limitations of that act, passed in I940, could easily be avoided by organizing many political committees, by having each union local act as a separate associa-

\footnotetext{
${ }^{6}$ Lonegran Report at 24, 26. Labor's share of total contributions in aid of the Democratic Party was $8.3 \%$ (as computed from Lonegran Report at 29). This was of real importance to the Democratic Party which had lost a great deal of its business support. Overacker, op. cit. supra note 3 .
}

${ }^{7}$ Lonegran Report at 127-33; Overacker, op. cit. supra note 3.

${ }^{8}$ Authorities cited supra note 7 .

${ }^{9}$ See Rosenfarb, Labor's Role in the Election, 8 Pub. Op. Q. 376 (I944).

Io Overacker, Campaign Finance in the Presidential Election of I940, 35 Am. Pol. Sci. Rev. 70I, 7×5-I6 (194r).

Ix Ibid. A token $\$ 2,000$ was spent to aid the Republican Party by Labor's Non-Partisan League, which was organized and controlled by Lewis. Rosenfarb, op. cit. supra note 9 .

${ }^{12}$ See Kallenbach, The Taft-Hartley Act and Union Political Contributions and Expenditures, 33 Minn. L. Rev. I-6 (I948).

${ }^{13} 43$ Stat. Io70 (I925), as amended, I8 U.S.C.A. $\$ \S 59 \mathrm{r}, 597,599,602,609$-610 (I950). For the most part the Act collected and systematized earlier legislation. Although it also outlaws a wide variety of fraudulent election practices, the main features of the Act are concerned with publicity requirements. Political committees which operate in two or more states or are part of larger political committees operating nationally are required to report all contributions received over one hundred dollars, itemize all expenditures over ten dollars, and total all contributions and expenditures. The reports are filed periodically with the Clerk of the House and have often been summarized by newspapers and congressional investigating committees. For a complete background of the Act, its history and effect, consult the following works of Overacker: Money in Elections (1932); Presidential Campaign Funds (I946); Campaign Funds in a Depression Year, 27 Am. Pol. Sci. Rev. 769 (r933); Campaign Funds in Presidential Election of $1936,3 \times$ Am. Pol. Sci. Rev. 473 (I937); Campaign Finance in the Presidential Election of I940, 35 Am. Pol. Sci. Rev. 70I (I94I); Presidential Campaign Funds, 1944, 39 Am. Pol. Sci. Rev. 899 (I945).

${ }^{14} 54$ Stat. $767,770,77^{2}$ (r940), as amended, I8 U.S.C.A. $\$ \S 608-9$ (r95o). 
tion, and by having the Internationals contribute five thousand dollars to each of many political committees. ${ }^{25}$

In I943 legislation directed specifically at labor's financing of political activity was first enacted. In that year the Smith-Connally Act amended Section 3I3 of the Corrupt Practices Act to prohibit labor organizations from making contributions in connecting with federal elections ${ }^{26}$ (not including primary elections or conventions of political parties ${ }^{17}$ ). These restrictions, enacted first in $1907,{ }^{18}$ had previously applied only to corporations. The stated purposes of the amendment of Section $3 \mathrm{I} 3$ were: (I) the protection of union members who disagreed politically with the majority of their union, and (2) the reduction of what Congress thought was the "undue influence" of labor on elections. ${ }^{x 9}$ This latter purpose stemmed from the growing feeling in Congress that labor had gained too much power generally under protective national legislation. As in the TaftHartley Act, the attempt was made to equalize the treatment of labor and corporate management.

In July 1943 the CIO organized the Political Action Committee, which, except on paper, was little more than a branch of the CIO. ${ }^{20} \mathrm{PAC}$ stated that it would operate as if it were a labor organization, ${ }^{2 x}$ even though in the Attorney-

${ }^{25}$ Section $I_{3}(b)(x)$ of the Act originally limited any "person" (defined as any "individual, partnership, committee, association, corporation, [or] any other organization or group of persons"). 54 Stat. 770 (1940). The phraseology of the Section was later changed to read: "Whoever ... makes contributions. . " but this change did not affect the substantive meaning. I8 U.S.C.A. $\$ 608$ (I950). Many locals of the same international could probably make contributions on the assumption that each constituted a separate association for the purpose of the Act. Since locals are so numerous, this would destroy any limitations on labor which the Section might have had. CIO unions also evaded Hatch Act II in rg44 by having the CIO-Political Action Committee act as an educational rather than as a political organization during the primary period. Since educational organizations are not subject to the Act, unions felt free to contribute over the limit to PAC while it was technically operating in the "educational" field! Hearings before the Committee to Investigate Campaign Expenditures, H.R., 78th Cong. 2d Sess. 52-56, 9o (r944) (hereafter cited as the Anderson hearings). For a complete description of the effect of the Hatch Act consult the following works of Overacker: Presidential Campaign Funds (I946); Campaign Finance in the Presidential Election of $1940,35 \mathrm{Am}$. Pol. Sci. Rev. 70r (r94I); Presidential Campaign Funds, r944, 39 Am. Pol. Sci. Rev. 899 (I945).

${ }^{16}$ War Labor Disputes Act, 57 Stat. $163,167-68$ (1943). This amendment to Section 313 of the Corrupt Practices Act, 43 Stat. ro70, ro74 (r925), as amended, I8 U.S.C.A. \& 6ro (1950), was scheduled to expire six months after the cessation of hostilities. 57 Stat. I68 (r943).

17 The Corrupt Practices Act, Section 302, does not include primaries or conventions in its definition of elections. 43 Stat. ro7o (r925), as amended, r8 U.S.C.A. § 59r (I950).

${ }^{28} 34$ Stat. 864 (1907). 19 See United States v. CIO, 335 U.S. 106, II5 (1948).

20 The National Board was made up of officers of CIO Internationals. State Political Action Committees typically utilized the mechanisms of the State CIO Councils. Local Political Committees were set up as committees of the local unions. Shop stewards typically collected contributions. Part time workers for PAC, generally union officials, were sometimes paid by the unions. California practices were anomalous. State and Local union organizations did political work directly. The State Committee did not keep records. Report of the Special Committee to Investigate Campaign Expenditures, H.R. Rep. No. 2,093, 78th Cong. 2d. Sess. 5 (1944) (hereafter cited as the Anderson Report); 9 Anderson Hearings 9 II.

2x I Anderson Fearings 27. 
General's opinion it did not come under the Act's definition of a labor organization. ${ }^{22}$ Since primary conventions were not covered by Section $3^{\mathrm{I}} 3$, PAC felt free to receive contributions from trade unions and spend them until the conventions were over. ${ }^{23}$ Immediately after the I944 Democratic convention, PAC's Trade Union Account was frozen and the rest of its activities were financed by individual contributions. ${ }^{24}$ PAC interpreted the Smith-Connally Act as prohibiting political contributions by labor organizations but not direct political expenditures. ${ }^{25}$ Under this view the unions could not contribute to PAC (because PAC was a political committee), and PAC could not contribute to other political committees (because it was also acting as if it were a labor organization), but both were free to spend directly during the regular election period..$^{26}$ The Attorney-General and the Anderson and Green Committees (House and Senate investigating committees) found no violations of the law after investigations of PAC's activities throughout every phase of the 1944 campaign. ${ }^{27}$ As a result of the distinction between contributions and expenditures the Section was little more than an inconvenience to labor which spent more money in 1944 than in any previous election, an estimated $\$ I, 570,000 . .^{28}$

za Letter from Att'y Gen. to Senator Moore, Sept. 23, 1944. This letter is discussed in 57 Yale L.J. 806, 809 n. I4 (I948), and quoted in 4 Lawyers Guild Rev. 49 (I944). Section $3^{13}$ itself states the "labor organization" has the same meaning as under the National Labor Relations Act, where the following definition is set forth: "[A]ny organization of any kind, or any agency or employee representation committee or plan, in which employees participate and which exists for the purpose, in whole or in part, of dealing with employers concerning grievances, labor disputes, wages, rates of pay, hours of employment, or conditions of work." 49 Stat. $45^{\circ}$ (I935). This definition had been incorporated directly in Section 304 of the TaftHartley Act.

${ }_{23}$ The views of CIO-PAC are clearly stated in a letter of December 9, I943 to its regional directors, quoted in Report of the Special Committee to Investigate Presidential, Vice-Presidential, and Senatorial Campaign Expenditures, 1944, Sen. Rep. No. ror, 79th Cong. Ist Sess. $2 x-22$ (I945) (hereafter cited as the Green Report); See also I2 IRRM 2544 (I943) for the opinion of Lee Pressman, at that time General Counsel for the CIO.

Total contributions from unions in this period were $\$ 647,903.26$. Green Report, at 23 . All of the union contributions, some as high as \$roo,00o, came from their general funds and were not earmarked for political activity when collected. $x$ Hearings before the Special Committee to Investigate Presidential, Vice-Presidential, and Senatorial Campaign Expenditures, 1944, U.S. Senate, 78th Cong. 2d Sess. 29-32 (r944) (hereafter cited as the Green Hearings).

24 Green Report, at 22; Anderson Report; Green and Anderson Hearings, passim. PAC emphasized throughout the testimony that no coercion of union members was used. Nothing in the testimony contradicts this.

${ }^{25}$ Authorities cited note 23 supra.

${ }^{26}$ The International Brotherhood of Teamsters spent directly from its treasury during the regular campaign. Green Report, App. IV, I02-2I. [AFL unions agreed with PAC's interpretation. See Padway, Political Contributions, 5I American Federationist, No. 3, at 2425 (March, I933).] But no CIO unions spent directly except in California. There the state CIO council made expenditures from its legislative fund which was in part received directly from union treasuries, and one local even levied a twenty-five cent assessment per month to be used for political purposes. However, no prosecutions resulted. 9 Anderson Hearings.

27 Green Report, at 20-23; Anderson Report, at 8-9.

${ }^{28}$ This figure was arrived at from the following data: The total reported receipts of the national office of CIO-PAC from individual contributions amounted to $\$ 376,910$ with expendi- 
Section 304 of the Taft-Hartley Act, passed in I947, was an attempt to close the gaps in the Smith-Connally Act. Labor organizations were prohibited from making expenditures as well as contributions "in connection with any [federal] election ... or in connection with any primary election or political convention or caucus held to select candidates for any [federal] offices. . . ."29

The phrase "in connection with" leaves doubt as to what acts fall within the prohibition of the Act and also as to possible temporal limitations. It is often difficult to determine when an expenditure is "in connection with an election." Expressions of opinion on issues involved in a campaign without mention of party or candidates, distribution of voting records with no explicit approval or disapproval expressed, slanted news broadcasts and the like are all difficult to handle under the language of the Section..$^{30}$ Temporally, the unions interpreted it to mean that they were free to spend and contribute in the period after the close of an election and before the last date of filing for candidacy in the next primary election. ${ }^{3 x}$

tures from the individual contribution account of $\$ 470,852$. Expenditures from the Trade Union Account during the primary period were $\$ 478,498$. Green Report, at 23 . Although the AFL as a whole remained politically inactive, member unions reported receipts of $\$ 236,5$ IO and expenditures of $\$ 246,352$. Green Report, App. IV, at I02-2I. The finances of state and local committees of CIO-PAC were not reported. National CIO-PAC did not report the finances of state and local committees maintaining that it [national] served them in an advisory capacity only. The state and local committees maintained that they were not part of a national organization, and, therefore, did not have to report their finances, since the definition of political committees in Section 302 (c) of the Corrupt Practices Act includes only those committees which operate in two or more states or are part of larger committees operating nationally. 43 Stat. 1070 ( 1925$), 2$ U.S.C.A. $\$ 24$ I (c) (1927). However, the total amount received by all CIO Political Action Committees from individual contributions can beestimated in the following manner. Individual contributions were collected by the local committees with fifty cents of every dollar forwarded to the national office and the remainder split between the local and state committees. 9 Anderson Hearings 709. Therefore, the total retained receipts of all local and state committees from individual contributions can be estimated as equal to the $\$ 376$,9ro reported as the total receipts of the National Committee from individual contributions. If expenditures from this account were equal to receipts, the expenditures of local and state committees would be approximately $\$ 376,9 \times 0$. (There were no indications in the testimony before Congressional Committees of union contributions to the local and state committees during the primary period.)

There were undoubtedly disguised expenditures, such as political commentary in union newspapers, which were not reported and which the estimate does not allow for. The total expenditures of labor, as estimated, were $2 \mathrm{x} . \mathrm{r} \%$ of the total spent in aid of the Democratic Party and $7 \%$ of the total spent in the campaign. Computed from Overacker, Presidential Campaign Funds I944, 39 Am. Pol. Sci. Rev. 899 (I945).

${ }^{29} 6$ r Stat. ${ }_{59}$ (I947), I8 U.S.C.A. \$6ro (Supp., I950); see Kallenbach, The Taft-Hartley Act and Union Political Contributions and Expenditures, 33 Minn. L. Rev. I (I948); Section 304, Taft-Hartley Act: Validity of Restrictions on Union Political Activity, 57 Yale L.J. 806 (1948).

${ }^{30}$ See 93 Cong. Rec. 6,438-40, 6,446, 6,447 (I947); United States v. CIO, 335 U.S. xo6, I36 n. I3, I5I (I948).

31 Following the x 948 election Labor's League for Political Education, the AFL counterpart to CIO-PAC, collected $\$ 582,654$ directly from the trade unions to be used until Feb. Ist, I950, the filing deadline of the first primary. LLPE r949 Minutes 2. This is one of the many possible interpretations. See United States v. CIO, 335 U.S. Io6, I5I (1948). 
Interpreted literally, "expenditures" might encompass much of the effective political activity in which a union or its officers and agents may engage and would seem to be an abridgement of free speech. ${ }^{32}$ To meet this objection, Senator Taft argued throughout Senate debate that unions could publish political views in union newspapers if the money used came from voluntary individual contributions or subscriptions rather than union funds. ${ }^{33}$ Emphasizing that the primary objective of the Section was to protect the rights of dissenting members, ${ }^{34}$ Taft stated that he had no objection to an organization like PAC, if it were financed solely by individual contributions which were not deducted from dues. ${ }^{35}$ This "source of funds" test was his answer to every question raised in the Senate as to the scope of "expenditure," although the test is neither explicit not implied by the language of Section 304. The policy considerations behind restrictions on labor's political financing as outlined previously in connection with the Smith-Connally Act were all brought forward in Senate debate by the proponents of Section $304 \cdot{ }^{36}$

Section 304 was first interpreted by the courts in United States v. CIO..$^{37}$ The CIO News, financed from the CrO treasury, published an editorial urging the election of a candidate in a federal election. To remove doubt that an expenditure was involved, one thousand extra copies were printed and distributed in the election district. The Supreme Court, speaking through Justice Reed, construed the Section so as to avoid passing on its constitutionality. It found that the CIO published and distributed the paper "in regular course" and "to those accustomed to receive" it..$^{8}$ The Court felt that if "union periodicals published regularly for members" 39 were prohibited by Section 304 , the Section would be of doubtful constitutionality..$^{\circ}$ Distinguishing the publication and circulation of such periodicals from "occasional pamphlets," "dodgers," and the wide distributions of "free copies," Justice Reed held that explicit language in the section would be required to convince the Court that Congress intended to restrict a regular publication expressing political views. ${ }^{4}$ Not finding the necessary express prohibition, the Court concluded that the use of general union funds for regular publications was outside the coverage of Section $304.4^{42}$ Thus stated, the opinion of the Court rejected the source of funds test as to regular

${ }^{32}$ See authorities cited note 29 supra for full discussion of the constitutional question.

3393 Cong. Rec. 6,436-4I, 6,445-48,6,522-24, 6,530 (r947).

34 Ibid., especially at 6,440 .

${ }^{35} 93$ Cong. Rec. 6,440 (I947).

${ }^{36} 93$ Cong. Rec. 6,436-4r, 6,446-48 (I947).

${ }^{37} 77$ F. Supp. 355 (D.C., I948), aff'd 335 U.S. 106 (I948), noted 47 Mich. L. Rev. 408 (I949), 27 N.C.I. Rev. 22 (I949), [I949] Wis. L. Rev. I84, 23 St. Johns I. Rev. I43 (I949); Kallenbach, op. cit. supra note 29 , at $14-18$.

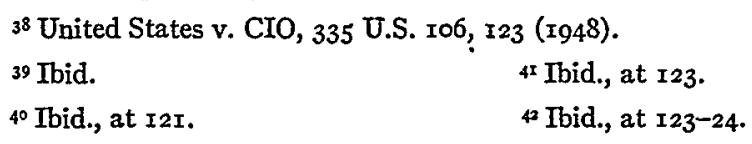


union publications. 43 This was in the teeth of clear statements on the Senate floor by the sponsor of Section 304 that the test should be applied in such situations. ${ }^{44}$ Attempting to meet this difficulty, the Court found a close similarity between the voluntary contributions or subscriptions necessary to satisfy the source of funds test and the implied consent of the membership to the use of their dues for such normal organizational activities of the union. ${ }^{45}$ Although such an inference of consent may be warranted as to the majority of union members, this reasoning ignores the fact that the main object of the source of funds test was the protection of minority members. ${ }^{46}$ The source of funds test would apply, the Court implied, to publications not within the exempted "regular course" category and to other political activity. 47 Four justices concurred in the result but urged that Section 304 , the tests advanced in Senate debate, and the majority's opinion were ambiguous,,$^{8}$ and also criticized the majority for usurping the legislative function by abandoning the source of funds test. ${ }^{9}$ They thought that Section 304 was unconstitutional whether interpreted literally or as qualified either by the source of funds test or by the tests set forth by the majority. .0 $^{\circ}$

Although the Court at one point implied that only distribution to union members was permissible, ${ }^{5 x}$ it also stated that a union paper could be distributed, at the union's expense, "to those accustomed to receive it." 52 While not free from ambiguity, the latter phrase would seem to negate the prior implication..$^{53}$ "To those accustomed to receive it" probably cannot mean only union members,

43 In the first part of the opinion, the Court asserted that the indictment did not allege an offense under the section, since it merely stated that the CIO News was financed from the CIO's funds without specifying the source of these funds, thus suggesting that the source of funds test had been met. The latter part of the opinion, however, leaves little doubt that source of funds is immaterial if the union newspaper is published and distributed in regular course to those accustomed to receive it. The concurring minority read the opinion as a general holding that union papers published and distributed in regular course to those accustomed to receive them need not meet the source of funds test, ibid., at 130-3r, especially n. 4, as did the Court of Appeals for the Second Circuit in United States v. Painters Local Union No. 481, I72 F. 2d 854 (C.A. 2d, I949). See p. 379 infra.

1493 Cong. Rec. 6,437-40 (1947). Some of these apparently clear statements were even quoted in the Court's opinion. 335 U.S. I06, II6-120. At one point the Court stated that "[o]ne can find indications in the exchanges between participants in the debate that informed proponents and opponents thought that [\$304] went so far as to forbid periodicals in the regular course of publication from taking part in pending elections where there was not segregated subscription, advertising or sales money adequate for its support." 335 U.S. 106, 122 (I948).

45 United States v. CIO, 335 U.S. 106, 123 (1948). ${ }^{6} \mathrm{P} .37^{6}$ supra.

47 United States v. CIO, 335 U.S. I06, I23-24 (I948).

$4^{8} \mathrm{Ibid}$. , at $\mathrm{x}_{32}, \mathrm{I}_{34}, \mathrm{I}_{4} \mathrm{I}_{-42}, \mathrm{I}_{46-47}$, I50-55.

49 Ibid., $137-39$.

so $\mathrm{Tbid}$., at $\mathbf{5}_{50-55}$. Speaking for the minority, Justice Rutledge reasoned that statutes restrictive of freedoms must be narrowly drawn to meet the precise evil which the legislation seeks to curb and that affected persons or groups must be able to calculate the legality of their actions. Ibid., at $141-42$.

$5 x$ Tbid., at $125, \mathrm{x} 23$. 52 Ibid., at 123 .

s3 The minority interpreted the phrase as possibly allowing insubstantial distribution outside the membership. Ibid., at I 3 I n. 5 . 
since union papers are in many cases distributed to nonmembers as well. Probably the section as interpreted would not exclude new subscriptions to a union paper. But if new subscriptions are allowed, difficulty arises when, as is commonly the case, there is no charge for the paper. Could numerous copies of an election edition of a union paper which normally was distributed without charge be circulated in the community on the theory that the recipients were new subscribers? The courts might ban distribution of this kind by applying another distinction made in the $C I O$ case, between union papers regularly published for members and free copies widely distributed. 54 However, a new paper which no one is accustomed to receive is more diffcult to handle under the rule of the $C I O$ case. The qualification "published and distributed in regular course" is also ambiguous. If interpreted to mean a normal organizational activity, as the Court implies, ${ }^{55}$ the question of innovation arises. Certainly unions are not to be limited completely to their past practices; but if not, where is the line to be drawn? The Court's opinion is silent on this point.

Thus the $C I O$ case, departing from the language of the Section and from the test set out in legislative debate, created ambiguous new tests not easily applicable to particular situations.

Taking immediate advantage of the $C I O$ opinion, labor made extensive use of union newspapers in the I948 campaign. ${ }^{66}$ Other types of paid political activity not covered in the decision presumably still had to meet the source of funds test. ${ }^{77}$ Accordingly, CIO-PAC and Labor's League for Political Education (AFL) were financed completely by individual contributions..$^{8}$ Nevertheless political expenditures of labor, estimated from reported figures, were $\$ \mathrm{I}, 280,000$ in $\mathrm{r} 948$ as compared with the estimated $\$ \mathrm{I}, 570,000$ in 1944 , a fact which indicates that labor's political expenditures were not appreciably decreased by Section 304.59

$54 \mathrm{Tbid}$. , at $122-23$. The Court read the indictment as charging only that the one thousand extra copies distributed in the case were published and distributed in regular course to members or purchasers and that no allegation was made of free distribution to those not regularly entitled to receive it. Ibid., at III-I2.

55 Ibid., at $r 23$.

${ }^{6}$ For example, in the $x 948$ election three million copies of Labor, the railway unions" paper, were distributed by LLPE. LLPE 1948 Minutes II (r948). It is not known whether LLPE paid the railway unions for the paper or whether LLPE received payment from the final recipients. It is quite clear that the paper was not distributed to members of the railway union since LLPE would not have been needed as distributing agent if that were the case. It is also clear that LLPE had never before taken three million copies of Labor, since LLPE was not in existence before the I 948 campaign. Labor's circulation was only $75^{\circ}, 000$ in 1945 . Peterson, American Labor Unions I49 (I945). These activities resulted in no prosecutions.

57 United States v. CIO, 335 U.S. I06, x23-24 (1948).

${ }^{58}$ N.Y. Times $\S$ I, p. 6, col. I (Oct. 3I, I948). LLPE I948 Minutes. PAC did report \$1 5,000 spent out of its Trade Union Account, probably spent in the pre-primary period and in State Elections. N.Y. Times, supra.

${ }^{59}$ The method of arriving at this total is the same as that used to arrive at the r 944 figure. See note 28 supra. The National office of CIO-PAC reported receipts of $\$ 363,295$ and expendi- 
In United States v. Painters Local Union No. $481^{60}$ decided after the 1948 election, labor made another attempt to test the constitutionality of Section 304. The union, which had no newspaper of its own, advocated the defeat of certain candidates in federal elections by means of a radio broadcast and an advertisement in a regular daily newspaper of general circulation. Expenditures for this purpose were approved by the membership at a duly held meeting and were made from the union's general funds, derived from dues and fees, and not earmarked on collection for such use. By thus failing to meet the source of funds test, the expenditures would presumably be prohibited unless brought within the rule of the CIO case. Since a regular union publication was not involved, the facts were distinguishable from those in the $C I O$ holding; but the court did not find the differences controlling. Judge Augustus Hand said:

It is hard to imagine that a greater number of people would be affected by the broadcast and advertisement in the present case than by publication in the union periodical dealt with in the CIO litigation. In a practical sense the situations are very similar, for in the case at bar this small union owned no newspaper and a publication in the daily press or by radio was as natural a way of communicating its views to the membership as by a newspaper of its own. . . .

Thus the holding extended the area in which the source of funds test was discarded so as to allow the use of other media of political expression where a union publishes no newspaper.

tures of $\$ 446,832$ from individual contributions. N.Y. Times, p. 7o, col. 3 (Oct. 31, r948). The total receipts of all CIO-PAC organizations (national, state, and local) can be estimated at $\$ 726,590$ and expenditures at $\$ 810,627$, using the same method as was used to arrive at the I 944 figures. See note 28 supra. Estimated in this way, total expenditures of CIO-PAC in r 944 were $\$ 1,326,2 \times 6$. The lack of direct contributions from the trade unions accounts for the considerable drop. Individual contributions for both campaigns were about equal.

The 1948 campaign marked the first real entrance of the AFL into politics. LLPE maintained that it was a nonpartisan organization; but, like PAC, it supported mainly Democrats. See LLPE 1948 Minutes. Individual contributions to LLPE totaled \$3I9, rII. LLPE 1948 Minutes 2. The International Ladies Garment Workers Union Campaign Committee reported receipts of $\$ x_{5}, 226$. N.Y. Times $\S x$, p. I4, col. 4 (Oct. 26, r948). The Trainmen's Political Education League reported receipts of $\$ 32,000$. Tbid. These two were the only major AFL organizations which did not work through LIPE and even they cooperated with it. LLPE I948 Minutes 2. Total reported receipts of AFL political organizations were $\$ 466,337$, and expenditures can be estimated to be about the same.

The only reported labor contribution to the Progressive Party was $\$ 5,000$ contributed by the New York Fur Workers Committee. N.Y. Times $\S$ I, p. 5, col. 8 (Nov. 2, 1948). Undoubtedly many union members contributed, but these contributions would not show in the record.

October 3 I figures are the latest available for the I 948 campaign except for the Fur Workers contribution cited. No special study or investigating committee reports exist, and, since the Clerk of the House does not send out filed figures, newspaper accounts are the only source. The figures do not allow for unreported expenditures which were probably greater in 1948 than in 1944 because of the pressure on unions to disguise political expenditure.

${ }^{60} 172$ F. 2 d 854 (C.A. 2d, I949), noted 49 Col. L. Rev. 1152 (r949), 7 Wash. \& Lee L. Rev. 87 (1950).

6s United States v. Painters Local Union No. 48x, I 72 F. 2 d 854,856 (C.A. 2d, 1949). 
A possible limitation on the use of union funds allowed under the Painters case is that such irregular expenditures may have to be approved by a majority vote at a duly held meeting. Hand equated the approval by majority vote in the Painters case with the implied consent of the membership to the use of funds for normal organizational activity in the $C I O$ case. ${ }^{62}$ The difficulty of evaluating the importance of the implied consent argument in the Supreme Court opinion makes it impossible to decide how important this majority approval argument is in the Painters case. In any event, the majority approval argument runs counter to the principle of minority protection.

By its broad extension of United States v. CIO, the Painters decision has largely emasculated Section 304. The limitation that distribution must be to union members has been eliminated by the Painters case. While union members undoubtedly received the communications in that case, members of the general public were also part of the audience. At least a sizeable portion of the membership knew of the union's position since the expenditures were approved at a duly held meeting. This, in addition to the media selected, suggests that the communications were directed primarily at the general public, not union members. The rule of the case seems to be that it makes no difference how many people are reached by the communication or to whom it is directed, so long as union members are part of the audience.

The limitation of the case to those unions without papers of their own will not hinder the labor movement from taking full advantage of the decision. The International to which the local in the Painters case belonged publishes a periodical. ${ }^{63}$ The case holds, therefore, that any local which does not have its own newspaper (and most do not) ${ }^{6} 4$ is free to indulge in the political publicity described.

Since the Painters case was decided after the I 948 election, its full effect will not be accurately measured until 1952 . The boundary lines of the case are not clearly fixed. Political pamphlets may come within the rule of the Painters case, as might expenses for union political meetings, on the theory that they are in the nature of communications to union membership. This argument will not apply as easily to certain other campaign paraphernalia (buttons, banners, billboards etc.) which may still have to meet the source of funds test, as might paid precinct workers who contact union members, union political organizers, and union political office expenses. Even these might be brought within the rationale of the case as being "as natural a way of communicating its views to the membership as by a newspaper of its own." $6_{5}$ Except for some inconvenience due to decentralization of expenditures, the prohibition on contribu-

62 Ibid.

${ }^{63}$ The local belongs to the Brotherhood of Painters, Decorators and Paperhangers. International Labor Directory 60I (I950). The Brotherhood publishes Painter and Decorator. Peterson, op. cit. supra note 56 , at 157 .

${ }^{6} 4$ Some very large locals have papers. Peterson, op. cit. supra note $5^{6}$, at $5_{5} \mathrm{I}$.

65 United States v. Painters Local Union No. 48 I, I72 F. 2d 854, 856 (C.A. 2d, I949). 
tions, and some campaign paraphernalia, labor is probably free to indulge in almost every type of paid political propaganda under the rule of the Painters case.

Under Section 304 the minority member is not adequately protected because union funds can be spent directly under the $C I O$ and Painters cases, and the loopholes left by these cases provide little protection against any undue influence which labor might have. The law is uncertain and the constitutionality of Section 304 is still in doubt.

\section{GREAT BRITAIN}

Even before the formation of the Labour Party, British trade unions financed political campaigns. ${ }^{66}$ Since the beginning of the movement for an independent labor party, trade unions have supplied almost all its funds and are today the Labour Party's main source of financial support. ${ }^{67}$

There were no fetters on trade union political activity ${ }^{68}$ until Osborne $\%$ A malgamated Society of Railway Servants, ${ }^{6}{ }_{9}$ decided in I9Io. Osborne, a member of the union, objected to a levy on the membership to be used to elect members of parliament and pay them stipends. The case rested on the narrow, and widely criticized, ${ }^{70}$ ground that political activity was not included in the powers of a trade union as defined by the Trades Union Act of $1876 . .^{7 x}$ The decision com-

${ }^{66}$ The Webbs, The History of Trade Unionism, 685 and c. Ir generally (rev. ed., I920); Cole, British Working Class Politics $1832-\mathrm{rgI}_{4}$ (194I).

${ }^{67}$ See the accounts of the Labour Party, published in the Reports of the annual Conference of the Labour Party. Almost the entire membership of the Labour Party consists of union members. The Report of the 48th Annual Conference of the Labour Party 35 (I948). See books by Cole, op. cit. supra note 66, and A History of the Labour Party from I9I4 (I948), for studies of the relationship of the trade unions to the Labour Party in these and other aspects.

${ }^{68}$ Laws regulating the entire nation did, of course, apply to labor. The basic laws are: The Corrupt and Illegal Practices Prevention Act of 1883,46 \& 47 Vic. c. $5^{\mathrm{I}}$, Part III, Sections 25, 26, 27, 29, 33, 34, Schedule IV (r883); Representation of the People (Equal Franchise) Act of 1928 , 18 \& $x_{9}$ Geo. V, c. 12 , Section 5 (1928). See Pollock, Money and Politics Abroad, Part II (1932) for a full description of British Campaign finance and its regulation. See also Overacker, Money in Elections $2 \mathrm{Ir}-27$ (1932) for a briefer discussion. Briefly, the legislation provides strict limitations on the amounts which can be spent by or on behalf of a candidate during the relatively short formal election period, but places no limitations on the amounts which can be spent by parties or pressure groups so long as a particular candidate is not mentioned by name.

${ }^{69}[\mathrm{rg} 99]$ I L.R. Ch. D. 163 , aff'd [I9ro] A.C. 87 .

${ }^{70}$ See The Webbs, op. cit. supra note 66, at 6ro-3r, and Geldart, The Present Law of Trade Disputes and Trade Unions, I Pol. Q., No. 2, at I7 (May, I9I4), for criticism and a more complete discussion of the decision.

${ }^{71} 39$ \& 40 Vict. c. 20, Section 16 (I876). Three members of the upper court decided the case on the narrow statutory grounds. Lords Shaw and James, however, were concerned with a rule adopted by the union making it mandatory for candidates supported by them to subject themselves to the Labour Party "whip." The case also turned on the narrow grounds in the lower court, but two of the three members of the court discussed broader issues of political freedom. Concluding that forcing a dissenting member to pay such a levy would impinge upon his political rights, they refused to distinguish between coercing a member to vote in a particular way and forced political contribution, and held both to be violations of individual rights and inimical to the democratic process. 
pletely prohibited the unions from any political action and thereby dealt a serious blow to the recently formed Labour Party. ${ }^{72}$

The Trade Unions Act of $19^{1} 3^{73}$ again permitted unions to spend money for political objects, ${ }^{74}$ subject to certain limitations. A majority of those union members voting had the power to decide what political objects, if any, the union would support. ${ }^{75}$ Political expenditures had to be drawn from a separate political fund. ${ }^{76}$ Any member who objected to contributing could "contract out," that is, exempt himself from financial support of political activity by written notice. ${ }^{77} \mathrm{~A}$ dissenting member could contract out at any time and his exemption continued until he formally withdrew his notice. ${ }^{78}$ Power over the political fund was vested in those not contracting out. ${ }^{99}$ The union was prohibited from placing any member who contracted out at a disadvantage as compared with other union members, ${ }^{80}$ nor could contributions be made a condition of admission to the union. ${ }^{8 x}$ The union was required to inform the members of their right to contract out. ${ }^{82}$ Funds could be collected either by separate levy or by relieving those who had contracted out of that part of union dues which went into the political fund..$^{83}$ The unions' rules and practices for these procedures were subject to the approval of the Registrar of Friendly Societies, who also audited the unions' books and published his accounting..$^{{ }_{4}}$

Political funds could be used to pay candidates' campaign expenses; to maintain members of parliament or holders of other political offices; in connection with the selection of candidates; and for political meetings and political literature of any kind.$_{5}{ }^{8}$ Expenses could be defrayed from the union's general funds, however, if the "main purpose" of a meeting or literature was the furtherance of the union's "statutory objects," tween workmen and masters or between workmen and workmen." newspapers came under the "main purpose" test. 88

$72 \mathrm{It}$ is impossible to say exactly how seriously the unions were affected, since there are no records of union expenditures before the decision.

732 \& 3 Geo. V, c. 30 ( $\mathrm{Ig}_{3} \mathrm{I}_{3}$ ). See Geldart, op. cit. supra note 7o, and Rothschild, Government Regulation of Trade Unions in Great Britain II, ${ }_{3} 8$ Col. L. Rev. I335, 1360-66 (1938), for analysis of the entire act.

, 74 Trade Unions Act, 2 \& 3 Geo. V, c. $30, \S \S$ I, 2(I) (I9r3).

\begin{tabular}{|c|c|c|}
\hline $\begin{array}{l}75 \text { Ibid., } \S_{3}(\mathrm{I}) \\
{ }^{6} \text { Tbid., } \S_{3}(\mathrm{I})(\mathrm{a}) \text {. } \\
77 \text { Ibid. }\end{array}$ & $\begin{array}{l}{ }^{78} \text { Ibid., } \$ \S 5(\mathrm{I}), 5^{(2)} \text {. } \\
{ }^{79} \text { Ibid., } \$ 3(\mathrm{I})(\mathrm{b}) \\
{ }^{80} \text { Ibid. }\end{array}$ & $\begin{array}{l}{ }^{8 x} \text { Ibid. } \\
8 z \text { Ibid., } \S 5(x) . \\
8_{3} \text { Ibid., } \& 6 .\end{array}$ \\
\hline
\end{tabular}

$84 \mathrm{Ibid} ., \S_{3}(\mathrm{r})$. This was bitterly criticized by labor. I Parl. Affairs $47-5^{\circ}$ (x948). Political parties are not required to make public either the source or amount of funds. Since most of the Labour Party's funds come from the trade unions, authorities cited note 67 supra, this publication put the Labour Party at a tactical disadvantage.

85 Ibid., § 3(3). ${ }^{86}$ Tbid., $\S 3(3)$ (e).

${ }^{87}$ Section I(I), ibid., defines "statutory objects" as the objects mentioned in the Trade Unions Act of $1876,39 \& 40$ Vic. c. $22, \S 16$, which is quoted in the text.

${ }^{88}$ See Bennett v. Nat'l Amalgamated Society of Operative Painters, Ir3 L.T. 808, 8Ir, 85 L.J. Ch. D. 298,300 (I9I5). An amendment to include union newspapers under this Section 
Following the general strike of 1926 , a Conservative government passed the Trade Disputes and Trade Unions Act of $1927{ }^{89}$ which substituted a "contracting in" system for the contracting out method of the I9I3 Act. Under the I927 Act only those members who signed a statement of their willingness to contribute were required to pay the political levy. ${ }^{\circ 0}$ This put the burden of action upon the union. The union lost the contributions of many forgetful, forgotten, and indifferent members. Whereas the I9I3 Act presumed that the majority wanted to contribute and made special provisions for dissenting members, the presumption of the I927 Act was the exact opposite. The theory underlying this change was that dissenting members were discouraged from contracting out by fear of discrimination, even though such discrimination was expressly forbidden by the I9I3 Act.9r The change in system did not, however, decrease the risk of discrimination against dissenting members. ${ }^{92}$ Under both systems dissenting members were known to the union officers and to the majority of members paying the political levy. The attitude of the majority toward the minority would not be affected by the change.

Another change in the system resulted from charges that under the I9I3 Act part of the dues of contracting out members found their way into the political fund. ${ }^{93}$ Although the Registrar of Friendly Societies found no such violations, ${ }^{94}$ the I927 Act provided that unions could not take the political levy out of the regular dues of those members who contracted in, but the unions had to make a separate levy.95 This provision, together with the shift from contracting out to

had been passed by the House of Lords but rejected by Commons. Geldart, op. cit. supra note 70 , at 60 . The Attorney General had stated in debate that the Section as it stood did not include union newspapers. Ibid.

${ }^{89}$ I7 \& I8 Geo. V, c. 22 (I927); see Millis, British Trade Disputes and Trade Unions Act, 36 J. Pol. Econ. 305,324 (r928), and Rothschild, op. cit. supra note 73, at $1372-89$, for analysis of the entire Act.

${ }^{\circ} \mathrm{Ibid} ., \S_{4}(\mathrm{I})$.

${ }^{2}$ The small amount of litigation casts doubt on the validity of this argument. According to Millis only sixty-eight complaints of any worth were lodged under the rox 3 Act, twenty-six of which were found to be not within the law, "while a fair proportion of the remaining fortytwo" were found to be "without merit." Millis, op. cit. supra note 89, at 324. The cost, the difficulties of proof, and the risk of increased discrimination might have discouraged desired litigation, but there must have been persons eager to finance such litigation in view of the political harm that would be done thereby to the Labour Party. The dissident member in the Osborne case was "liberally financed from capitalist sources." The Webbs, op. cit. supra note 66 , at 608 .

${ }_{92}$ Perhaps it made it more likely that members in disagreement with the unions' political objectives would not contribute to the political funds, since it was perhaps psychologically easier to fail to contract in rather than take the positive action which contracting out involved.

${ }_{93}$ See Millis, op. cit. supra note 89 , at 323 . He concluded that these charges were unsubstantiated.

94 Ibid. Dues were levied on a uniform per capita basis; a separate political fund was maintained; and a dissenting member was allowed to withhold the political part of his dues. Therefore, any irregularities would be likely to show up on the books of the union which were under the closest scrutiny by the Registrar of Friendly Societies.

95 Trade Disputes and Trade Unions Act, I7 \& I8 Geo. V, C. 22, § 4(2) (I927). 
contracting in, created burdensome administrative tasks for the unions. Immediately after the 1927 Act was passed the political expenditures of the trade unions and the Labour Party dropped considerably. ${ }^{96}$

In 1946 the I927 Act was repealed by the Labour Government, and the I9I3 Act again became law. ${ }^{97}$ Contributions to the Labour Party in 1948 from the political funds of the unions were more than double those of I944, both nonelection years. ${ }^{88}$ Both Labour Party expenditures ${ }^{99}$ and expenditures from the unions' political funds in 1948 were about two and one-half times greater than in $1944 .{ }^{\text {xoo }}$ The figures for I948 are higher than for the election year of 1945 in all respects aforementioned. ${ }^{\text {.0r }}$ Although many immeasurable factors influenced labor's political expenditures and contributions, the drop immediately following the I927 Act and the increase immediately after 1946 indicate a causal connection between the changes in system and the size of labor's expenditures and contributions.

\section{CONCLUSION}

Comparison of American and British legislation regulating labor's political activities is made difficult not only by disparities in political climate, institutions, and practices, but also because there are no exact parallels in the mechanics of the two systems. ${ }^{\text {102 }}$ However, British experience with a system different in its approach may be of value to American policy makers. Policy considerations underlying any system of regulations are exceedingly complex, embracing such broad problems as the proper political role of labor, the internal structure of the unions, the influence of money in politics, and the place of pressure groups in a democracy. Particular methods of regulating labor's financial role in politics must rest on some resolution of these broader problems.

${ }^{96}$ In $19264 \mathrm{r} .8 \%$ of the members of registered trade unions contracted out, and in 1929 $56.4 \%$ did not contract in; and the total receipts of political funds of registered trade unions were $£_{39,000}$ less in 1929 than in I924, also an election year. Percentages computed from figures at 244 H.C. Deb. I219-20 (5th Ser., I930). Written Answers, Col. I219-20 (Nov. 7, I930). Trade Union contributions to the Labour Party fell from a high of $£ 6$ I,II 8 in I925 to a low of $£_{25,989}$ in 1929 and for the next four years varied between $£_{35,000}$ and $£_{3} \mathrm{I}, 000$. Reports of the Annual Conference of the Labour Party for these years. Labour Party expenditures fell from a high of $£_{3,292}$ in 1926 to $£_{47,5} 86$ in r929, and remained within $£_{3}, 000$ of this figure for the next four years. Ibid.

${ }^{97} 9$ \& xo Geo. VI, c. 52 (1946). Significantly, the Labour Party was against the I9r3 Act when originally enacted, and all Labour M.P.'s voted against it. The Webbs, op. cit. supra note 66 , at 687 .

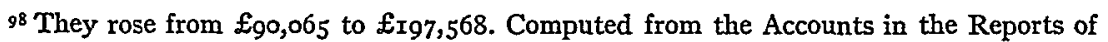
the Annual Conference of the Labour Party for these years.

99 They rose from $£ 64, I_{44}$ to $£_{59,905}$. Tbid.

${ }^{r 00}$ They rose from $£_{337,000}$ to $£_{375,000}$. Registry of Friendly Societies, Statistical Summary 1938-1948, Registered Trade Unions (I949).

ros Authorities cited notes 98 and roo supra.

${ }^{102}$ The superficial similarity of the contracting in system embodied in the British r927 Act to Senator Taft's source of funds test and the financing of PAC and LLPE from individual contributions should, however, be noted. 
Dissenting member protection, the main thrust of British legislation, was the primary justification given for Section 304 by its sponsors. Unlike the British systems, which directly regulated the internal affairs of unions, American legislation attempted to achieve this goal by blanket prohibition of all expenditures and contributions by unions in connection with Federal elections. The loopholes in the Section, those created by loose phraseology and limited temporal coverage as well as those read into it by judicial legislation, have resulted in a substantial collapse of the prohibitive scheme, thus leaving dissenting members largely unprotected. Prohibition more stringent than that left by the decisions would be of doubtful constitutionality. In the light of this development, it is suggested that protection of minority members can best be accomplished by provisions directly regulating the internal affairs of unions. ${ }^{\mathrm{x}} \mathrm{3}$ Although majority rule is an integral part of organizational activity, the fact that union membership is often a condition of continued employment provides strong justification for relieving the dissenting member from the necessity of financially supporting political activity..$^{\mathbf{1 0 4}}$ Both British acts employed this direct approach and they provide models for American legislation. ${ }^{\mathrm{I0}}$ The comparative working of two possible systems, "contracting out" and "contracting in," is illustrated by forty years of English practice. Other features of the (1948).

${ }^{103}$ This was the opinion of Rutledge concurring in United States v. CIO, 335 U.S. I06, 149

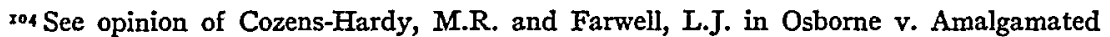
Society of Railway Servants [rgog] I L.R. Ch. D. I63, I75, I95. But cf. DeMille v. American Federation of Radio Artists, 3 I Calif. $2 d$ r39, 187 P. $2 d$ 769 (I947). In this case the union levied an assessment to be used to fight an anti-closed shop resolution appearing on the state ballot. DeMille refused to pay the assessment, was expelled from the union, and, because a closed shop agreement was in effect, lost his job. The California Supreme Court held that as long as the assessment was properly made under the union's constitution and rules, DeMille could be expelled for non-payment. The court held that DeMille's political rights had not been infringed upon, but, distinguishing the Osborne case, indicated that they would decide the other way if the election of a public official, rather than a referendum question, had been involved.

Although the Taft-Hartley Act outlaws the closed shop, union shop and maintenance of membership agreements are permitted. $\$ 8(\mathrm{a})(3)$, subject to state law. $\$ \mathrm{r}_{4}(\mathrm{~b})$. Under such an agreement an employer may discharge only an employee who has lost membership in the union because of non-tendering of "periodic dues." Ibid. Thus if unions were permitted to finance political activity and did so out of periodic dues, a dissenting member could be discharged (under one of the permitted forms of compulsory union membership) for withholding his dues; or, supposing he could determine the portion which was to be allocated to political activity (an unlikely supposition), for withholding that part of his dues. The NLRB has recently held that general assessments, levied at variable rather than regular times, are not "periodic dues" within the meaning of $\S 8(a)$ (3). International Harvester Company (Foundry Division, Louisville works) CCH Lab. Law Rep. I10,950, 95 NLRB No. 80 (195I). The Board specifically noted that one of the objects of the section was to protect against the DeMille case situation. The decision means that political work, if permitted, will have to be financed by regular dues, not general assessments, a restriction that will not afford the dissenting member much protection.

${ }^{105}$ Rutledge, concurring in the CIO case, cites the British Acts as an example of how minority members can be protected. 335 U.S. I06, 149 n. 26 (1948). 
British system, the requirements that political decisions be democratically arrived at, that minority members be protected against discrimination, and that political funds be segregated, also merit consideration. Intelligent legislation, with British experience as a guide, should be able to provide democratic procedures with adequate minority protection.

Section 304 was also motivated by a fear of labor's "undue influence" on elections. The argument was made that the large funds which unions could obtain from their huge memberships would enable them to dominate elections. Undue influence is, in any case, an elusive concept, and when used in connection with a single factor, union spending, which is a small and indistinguishable part of the total influence which unions might have on a national election, the concept is difficult to define and practically impossible to apply. Not only must the absolute amount spent by unions be considered, but also such other factors as the expenditure per member, the amounts spent by other groups and individuals, the uses to which the money is put, and the size of the unions relative to other groups and to the total electorate. ${ }^{106}$ Ignoring the complexities involved, Section 304 attempts to deal with the problem of undue labor influence by a blanket prohibition of the use of union funds for political activity. This is in sharp contrast with British legislation which has not concerned itself with this problem. ${ }^{107}$ If followed literally, the prohibitions in Section 304 would probably be held unconstitutional. Unwilling to follow the language of the statute, the courts have so restricted its scope that the section affords little protection against any undue influence which labor might have. If, therefore, labor's

I06 "'There is no showing, legislative or otherwise . . . of 'undue influence' so dominating as could possibly justify so absolute a denial of these basic rights." Rutledge in United States v. CIO, 335 U.S. IO6, I46 (1948). The evidence seems to support the conclusion that labor has not exercised an undue influence on elections by money expenditures. In I944 Labor's total expenditures (as estimated) were $\$ x, 570,000$, which constituted about $7 \%$ of the total campaign expenditures. Overacker, Presidential Campaign Funds (r946). In r944 business interests, as represented only by individual contributions of one thousand dollars or more, contributed about $\$ 9 I 8,212$ to the Democratic National Committee and the One Thousand Club (a Democratic organization) and $\$ r, 302,4 \mathrm{r}$ to the Republican National Committee and the United Republican Finance Committee. Overacker, 39 Am. Pol. Sci. Rev. 899, 908 (1945). In addition $\$ 306,07 \mathrm{I}$ in $\$ I, 000$ or over contributions to the Democratic organizations and $\$ 346,000$ to the Republican, were not identified as to interest. Ibid. A good part of these probably represented business interests. Two hundred and forty-two individuals representing 64 family groups contributed $\$ 1,286,609$ in the I944 campaign. Green Report, App. These figures represent only a portion of campaign contributions from business interests and indicate that labor has been well balanced by opposing groups in the matter of campaign finance despite labor's successful evasions of Section 304.

${ }^{107}$ The British have relied completely on general election laws. Note 68 supra. There might have been a time in the early history of the Labour Party when special limiting legislation against unions could have been enacted, but the Labour Party has been too powerful in recent years to allow this. The Act of 1927 indirectly had the effect of cutting down the size of the unions' political contributions and expenditures. Note 96 supra.

British unions, of course, exert great influence on elections through the Labour Party. Expenditures from the British unions political funds of about $f_{346,000}$ (about $\$ 1,384,000$ at the exchange rate of 1945 ) in the election year of 1945 (note 97 supra) compare with the estimated $\$ r, 570,000$ expenditure by American labor in the 1944 campaign. 
influence is to be feared, the failure of Section 304 points to the necessity of developing different means of control. Leaving financial controls completely aside, the Green Committee and Overacker have suggested strengthened publicity requirements as alternative methods. ${ }^{\mathrm{x}} \mathrm{8}$

Finally, restrictions on corporate political activity were also said to justify Section 304's identical prohibitions on labor by bringing these two powerful groups into political balance. Related to the undue influence problem, this argument was in line with the general purpose of the Taft-Hartley Act to put labor and management on an equal footing. But lumping unions and corporations together under the blanket prohibitions, as is done by Section 304, may not result in equality between them because of differences in structure, wealth, membership, and control of the media of mass communication. ${ }^{x 09}$ Closely tied in with the idea of balancing labor and management interests is another justification for classing corporations with unions in matters of political regulation. The aggregate power of these groups gives rise to legitimate fears that either or both might be able to dominate elections. Furthermore, their centralized structures might make such domination possible by a bare majority or even a numerical minority at the expense of large numbers of dissenting union members or stockholders. But here also distinctions should be made between corporations and unions. There are, for example, differences in the structure, history, and legal context of the decision making process, especially concerning minority members; in the type of interest of union members and investors due to differences in purpose and function; in the potential size of political contributions and expenditure; and in the scope of federal and state regulation. These and other distinctions may warrant different legislative treatment of corporations and unions. ${ }^{\text {Iso }}$ They certainly suggest that each organization should be considered separately in connection with the problems of undue influence and minority protection. Moreover, if the crucial problem is to control or reduce the power of large, well organized pressure groups and to protect minority members within them, the restrictions of Section 304 might well be broadened to cover all organized special interests by nondiscriminatory legislation that takes account, as Section 304 does not, of the differences between them.

British law presents the picture of a powerful parliament acting moderately,

${ }^{108}$ Green Report, at 83; Overacker, Presidential Campaign Funds, (1946).

rog If corporations and unions were both prohibited from making political contributions and expenditures, corporate interests could more easily raise money than labor interests, since the former could rely on large contributions from a relatively few individuals, while the latter must collect small amounts from many individuals. Furthermore, corporate interests are more adequately represented in the press and radio which are largely corporately owned and supported primarily by corporate advertising. On the other hand, the unions can rely to a greater extent on voluntary work from their large membership.

sxo"There are of course important legal and economic differences remaining between corporations and unincorporated associations, including labor unions, which justify large distinctions between them in legal treatment." Rutledge concurring in United States v. CIO, 335 U.S. 106, I54 (1948). 
with protection of the dissenting union member the keynote throughout. American legislation was extremely harsh and, read literally, completely prohibitive. Considerable watering down of Section 304 by the courts has resulted in uncertainty as regards both coverage and constitutionality and has enabled the courts to introduce criteria not necessarily relevant to the policy considerations underlying the statute. New legislation is called for. As to the protection of minority members, British legislation suggests possible solutions for the guidance of American legislators, but the problem of labor's undue influence is much more difficult. At best a difficult concept to define in the financial context of Section 304, the undue influence problem might better be handled by being left to general election laws, as in Great Britain; by strengthened publicity requirements; or by some system limiting but not prohibiting unions' financial participation in elections.

\section{CONTRIBUTION AND INDEMNITY'IN ILLINOIS NEGLIGENCE CASES}

The authorities agree that contribution between intentional co-tort-feasors should be denied since they are wrongdoers "not deserving of the aid of courts in achieving equal or proportionate distribution of the common burden."I It is also quite generally agreed that if one co-tort-feasor is adjudged liable for an injury although he was without fault, the law will grant total recovery, or indemnity, to the guiltless tort-feasor who has paid the injured person. ${ }^{2}$ While agreement thus exists when intentional or innocent tort-feasors are involved, controversy remains as to the right of contribution when the tort-feasors are negligent.

With the early English decision of Merryreather v. Nixan ${ }^{3}$ as a foundation, American courts at first refused to apply the rule against contribution among tort-feasors to cases involving mere negligence. 4 The origin and reason for the

× Commissioner's Prefatory Note to Uniform Contribution Among Tortfeasors Act, 9 U.L.A. 153 (1951).

2 E.g., George A. Fuller Co. v. Otis Elevator Co., 245 U.S. 489 (19x8); Grifiths \& Son Co. v. Nat'l Fireproofing Co., 310 Ill. 33 I, I4I N.E. 739 (I923); Farwell v. Becker, I29 Ill. 26I (1889). See Prosser, Torts III4 (r94r).

38 Durnf. \& E. I86 (K.B., I799). There is a very incomplete report of the case but the authorities seem agreed that the tort-feasor had acted in concert and wilfully. Later English cases so limited the decision, and held that the rule against contribution did not apply unless the plaintiff was a wilful wrongdoer. Betts v. Gibbins, 2 Ad. \& Ell. 57 (K.B., r834); Palmer v. Wick \& Pulteneytown Steam Shipping Co., [1894] A.C. 318.

4 Thweatt's Adm'r v. Jones, 22 Va. 328, ro Am. Dec. 538 (I823) (tobacco inspector may obtain contribution from co-inspector where their joint liability for conversion of tobacco did not arise out of intentional tort); Armstrong County v. Clarion County, $66 \mathrm{~Pa}$. 218, $5 \mathrm{Am}$. Rep. 368 (1870) (county held liable for injury resulting from negligent maintenance of bridge allowed contribution from another county jointly responsible for maintenance); Nickerson v. Wheeler, II8 Mass. 295 ( 1875 ) (other corporate officers liable in contribution to president whose property had been taken in satisfaction of execution obtained by corporate creditor against all officers personally liable because of failure to file certificates). 